\title{
PENINGKATAN KETERAMPILAN GURU SMA TERBUKA MELALUI PELATIHAN PEMBUATAN E-MEDIA
}

\section{IMPROVING OPEN SCHOOL TEACHER SKILLS THROUGH TRAINING OF E- MEDIA MAKING}

\author{
R W Wulandari 1a, N Maryani²
}

\author{
${ }^{1}$ Fakultas Tarbiyah, Institut Agama Islam Negeri Kediri \\ ${ }^{2}$ Fakultas Kegurugan dan Ilmu Pendidikan, Universitas Djuanda Bogor \\ aKorespondensi:Ratna Wahyu Wulandari; E-mail: ratnawahyuwulandari@iainkediri.ac.id \\ (Diterima: 29-12-2018; Ditelaah: 28-12-2018; Disetujui: 02-02-2019)
}

\begin{abstract}
Open School is a form of formal education that stands by itself but is part of a parent school that organizes education using the independent learning method. In open schools, students learn with the least help from the teacher and use modules as the main teaching material. Open-system learning provides the broadest learning opportunities for children graduating from elementary or junior high school or equivalent who cannot attend regular school education due to various obstacles they have. Community Service Activities conducted in the form of training activities aimed at conducting training and mentoring in making interactive learning media for Open High School teachers in Jonggol District, Bogor Regency. The expected target of this activity was able to improve the skills of teachers in operating electronic learning media maker applications. Applications used in making electronic learning media were Sparkol Video Scribe, Power Point, and Camtasia Studio. The method of this activity used the ABCD (Assets Based Community Development) method which was focused on developing human assets. The activities stage began with participant registration, followed by the delivery of material about electronic learning media, the process of installing applications, followed by the delivery of the main material about Sparkol Video Scribe, Power Point, or Camtasia Studio. The training was carried out three times face to face with different main material. The next stage was to provide an independent task to make learning media for participants in accordance with the teaching field concerned. As part of the refinement stage, participants were given assistance starting from the design, manufacture and finishing stage for 2 weeks. Each participant was required to produce 2 different media.
\end{abstract}

Keywords: training, mentoring, interactive learning media, open school, assets based community development.

\begin{abstract}
ABSTRAK
Sekolah Terbuka termasuk dalam lembaga pendidikan formal yang berdiri sendiri, tetapi penyelenggaraan pendidikannya masih mengikuti pedidikan dari sekolah induk. Sekolah terbuka memiliki penyelenggaraan pendidikan dengan metode belajar secara mandiri. Di sekolah terbuka, siswa belajar dengan bantuan dari guru seminimal mungkin dan menggunakan bahan ajar uata berupa modul. Pembelajaran dengan sistem terbuka memberikan kesempatan kepada anak-anak lulusan Sekolah Dasar atau Sekolah Menengah Pertama atau sederajat yang tidak dapat mengikuti pendidikan sekolah reguler karena berbagai hambatan yang dimiliki untuk menggali ilmu seluas-luasnya. Kegiatan Pengabdian bagi Masyarakat yang dilakukan ini berupa kegiatan pelatihan yang bertujuan untuk mengadakan pelatihan dan upaya pendampingan dalam pembuatan media sebagai bahan pembelajaran interaktif bagi guru-guru SMA Terbuka di Kecamatan Jonggol Kabupaten Bogor. Kegiatan ini memiliki target supaya guru sekolah terbuka dapat memiliki dan meningkatkan kemampuannya dalam membuat media pembelajaran dengan aplikasi yang dipelajari. Aplikasi yang digunakan dalam membuat media pembelajaran elektronik ini adalah Sparkol Video Scribe, Power Point, dan Camtasia Studio. Metode dari kegiatan ini menggunakan metode ABCD (Assets Based Community Development) yang difokuskan pada pengembangan aset manusia (human capital).
\end{abstract}


Tahapan kegiatan dimulai dari registrasi peserta, install aplikasi, dan pemaparan materi utama tentang Sparkol Video Scribe, Power Point, atau Camtasia Studio. Pelatihan dilakukan dengan cara peserta mempraktikkan langsung setelah materi disampaikan. Kegiatan praktik ini dilakukan sebanyak tiga kali tatap muka. Tahap selanjutnya yaitu memberikan tugas yang dikerjakan secara mandiri, yaitu membuat media pembelajaran, kepada peserta sesuai dengan bidang ajarnya. Tahap akhir yang disebut sebagai tahap penyempurnaan dilakukan dengan memberikan pendampingan membuat media pembelajaran sesuai mata pelajaran guru hingga tahap finishing yang dilakukan selama 2 minggu. Setiap peserta diharuskan menghasilkan 2 media yang berbeda.

Kata Kunci : pelatihan, pendampingan, media pembelajaran interaktif, sekolah terbuka, asset based community development.

Wulandari, R. W., \& Maryani, N. (2020). Peningkatan Keterampilan Guru SMA Terbuka Melalui Pelatihan Pembuatan E- Media. Jurnal Qardhul Hasan : Media Pengabdian kepada Masyarakat, 5(2), 3948.

\section{PENDAHULUAN}

Pasal 3 Undang-Undang Nomor 20 Tahun 2003 tentang Sistem Pendidikan Nasional, menjelaskan bahwa pendidikan nasional memiliki fungsi dalam mengembangkan kemampuan serta membentuk kepribadian peradaban bangsa menjadi bermartabat dalam rangka mencerdaskan kehidupan bangsa. Selai itu, pendidikan memiliki fungsi sebagai alat untuk meningkatkan potensi siswa sehingga siswa memiliki soft skills yang dapat menjadikannnya warga negara yang bertanggung jawab (Republik Indonesia, 2003). Oleh karena itu, salah satu skill yang perlu ditingkatkan oleh guru dalam menyelenggarakan pendidikan di kelas adalah penggunaan IT dan multimedia. Hal ini sesuai dengan Mayer yang berpendapat bahwa multimedia dapat digunakan untuk mengahsilkan teknologi pembelajaran yang dapat dinikmati secara verbal maupun visual (Mayer, 2009). Sedangkan Muhson menjelaskan bahwa teknologi pembelajaran pengaplikasiannya berupa pemanfaatan proses dan produk teknologi informasi dan komunikasi (information and communication technology/ICT) dalam hal ini untuk memecahkan masalah-masalah pendidikan dan pembelajaran, memiliki banyak manfaat atau keuntungan. Ini membuktikan bahwa penggunaan teknologi sangat penting dalam dunia pendidikan, yang mau tidak mau harus terus dikembangkan sesuai dengan perkembangan jaman (Muhson, 2010).

Penelitian Anwariningsih mengungkap bahwa 70\% guru-guru kelas belum mampu mengoperasikan komputer secara maksimal, sedangkan 30\%-nya telah mampu menggunakan komputer tetapi masih sebatas untuk keperluan mengetik tugas administrasi di sekolah (Anwariningsih, 2014). Saat ini teknologi sudah semakin maju, oleh karena itu dunia pendidikan juga harus mengikuti perkembangan teknologi yang ada. Terutama penggunaan teknologi pada sekolah terbuka.

Sekolah Terbuka termasuk dalam lembaga pendidikan formal yang berdiri sendiri, tetapi penyelenggaraan pendidikannya masih mengikuti pedidikan dari sekolah induk, dan menggunakan metode pembelajaran mandiri (Republik Indonesia, 2013). Sekolah terbuka merupakan alternatif untuk mengatasi permasalahan pendidikan formal yang menggunakan prinsip pembelajaran secara mandiri. Di sekolah terbuka, pembelajaran terhadap siswa dilakukan dengan memberikan bantuan seminimal mungkin dari guru dan modul digunakan sebagai bahan ajar utama. Sekolah terbuka ini digunakan sebagai lembaga pendidikan yang memberikan kesempatan belajar kepada siswa Sekolah Dasar dan Sekolah Menengah atau sederajatnya yang memiliki hambatan bersekolah di sekolah reguler. Siswa di sekolah terbuka ini bisa mendapatkan ijazah pendidikan formal, walaupun kegiatan 
pembelajarannya tidak dilakukan di sekolah reguler karena hambatan tertentu. Karena alasan itu Kemendikbud memfasilitasi anakanak dengan hambatan tersebut melalui Sekolah Terbuka, dimana siswanya terdaftar di Sekolah Induk, tetapi mengikuti kegiatan pembelajaran di Tempat Kegiatan Belajar (TKB). Kegiatan pembelajaran dilakukan secara rutin dan terjadwal, namun pelaksanaannya tidak seketat pendidikan reguler.

Permasalahan yang dihadapi dalam penyelenggaraan sekolah terbuka adalah kondisi geografis yang sulit, masalah sosial ekonomi, keterbatasan waktu, dan budaya. Hal ini berakibat pada terbatasnya anakanak usia 13-18 tahun untuk mendapatkan layanan pendidikan. Padahal melalui sekolah terbuka ini, siswa dapat mendapatkan layanan di bidang pendidikan yang dibutuhkannya. Lulusan Sekolah Terbuka sama dengan lulusan Sekolah Reguler. Hal ini berarti bahwa lulusan Sekolah Terbuka mempunyai hak dan kesempatan yang sama dengan lulusan Sekolah Reguler.

Pada dasarnya konsep pelaksanaan sekolah terbuka berbeda dengan pembelajaran di Sekolah Reguler. Prinsip pembelajaran di Sekolah Terbuka antara lain: 1) mandiri; 2) terbuka, tidak terbatas waktu dan tempat; 3) menggunakan pendidikan jarak jauh; dan 4) menggunakan berbagai jenis bahan ajar. Jenis pembelajaran yang disediakan juga berbeda, yaitu: 1) pembelajaran tatap muka, terjadi antara siswa berinteraksi dengan guru bina dan pembelajarannya dilaksanakan di sekolah induk, TKB, dan tempat lain yang disepakati; 2) pembelajaran mandiri, pembelajaran dilakukan oleh siswa secara perorangan atau kelompok tanpa kehadiran guru bina, dengan menggunakan modul dan media pembelajaran yang disediakan oleh guru; 3) pembelajaran online, digunakan dengan bantuan jaringan komputer menggunakan Learning Management System (LMS). Guru menyediakan materi, tugas, evaluasi dan materi pelajaran sesuai dengan kurikulum dan kebutuhan siswa.

Pembelajaran online atau pembelajaran jarak jauh dapat dilakukan dengan 2 cara: 1 ) sinkronus, guru mengadakan pembelajaran secara tatap muka langsung di TKB secara realtime; dan 2) asinkronus, dilaksanakan secara online tanpa tatap muka, siswa melakukan belajar secara mandiri dengan memanfaatkan bahan ajar elektronik (Dinas Pendidikan Provinsi Jawa Barat, 2017).

Pada tahun 2017-2018, Angka Partisipasi Kasar (APK) di Provinsi Jawa Barat perlu ditingkatkan, sehingga Pemprov Jawa Barat merasa perlu untuk melaksanakan Program SMA Terbuka. Berdasarkan data, remaja yang berusia 16-21 tahun yang tidak dapat melanjutkan pendidikan sekolah menengah memiliki angka yang relatif tinggi. Hal ini didasarkan pada APK Sekolah Menengah Jawa Barat yang terdata mencapai 76,6\%, hasil tersebut merupakan hasil paling rendah ke-2 se-Indonesia setelah Provinsi Papua. SMA Terbuka ini merupakan program dari pemerintah Provinsi Jawa Barat yang sudah dilaksanakan sejak tahun pelajaran 2017/2018 di berbagai wilayah seluruh Jawa Barat (Latip, 2017). Dengan adanya sekolah terbuka ini pelayanan pendidikan bisa meningkat dan semua anak harus sekolah dengan pelayanan bermutu karna berbasis teknologi. Untuk itu terus dilakukan himbauan agar orangtua bisa mendorong anaknya untuk mau bersekolah. Tidak hanya itu diharapkan juga orangtua bisa mengetahui tentang sekolah terbuka ini.

SMA Ar-Rahmah Jonggol yang merupakan salah satu dari SMA terbuka yang ada di Kecamatan Jonggol. SMA Ar-Rahmah Jonggol beralamat di Jalan Kampung Karni, Desa Jonggol, Kecamatan Jonggol, Kabupaten Bogor, Jawa Barat. Sekolah Ar-Rahmah Jonggol ini berada di bawah Yayasan ArRahmah, dan memiliki sekolah pada tingkatan SD, SMP dan SMA. Yayasan ini memiliki siswa-siswa yang memiliki hambatan-hambatan dalam melanjutkan pendidikan. Hambatan tersebut terdiri dari masalah sosial ekonomi, keterbatasan waktu, budaya, dan hambatan geografis.

Sejak tahun 2016, Yayasan Ar-Rahmah membuka SMA Terbuka untuk memfasilitasi siswa-siswa yang mengalami hambatan. Untuk mendapatkan ijin kegiatan pembelajaran secara resmi, SMA Terbuka Ar- 
Rahmah menginduk ke SMAN 1 Jonggol. Untuk penerbitan ijasah siswa SMA Terbuka juga menginduk ke SMAN 1 Jonggol.

Dalam pelaksanaannya, SMA Terbuka ini memiliki 25 guru bina untuk memberikan pembelajaran kepada siswa-siswa. Guru melakukan kegiatan pembelajaran yang diadakan secara tatap muka langsung atau sinkronus. Padahal, idealnya, pelaksanaan sekolah terbuka dilakukan secara sinkronus (melalui tatap muka) dan asinkrinus (tanpa tatap muka). Pembelajaran sinkronus dilakukan di dalam kelas seperti pembelajaran tatap muka pada umumnya. Untuk pembelajaran asinkronus, dilakukan secara mandiri dan menggunakan media yang diakses secara online, menggunakan media-media yang disediakan oleh guru, seperti modul, video, dan multimedia.

Permasalahannya, siswa-siswa yang terdaftar di SMA Ar-Rahmah ini melakukan pertemuan secara sinkronus saja. Hal ini dikarenakan belum adanya pengembangan media online yang disediakan oleh pihak sekolah. Dan media yang digunakan oleh guru masih konvensional dengan cara membagikan modul saat pertemuan berlangsung, yang mana seharusnya bisa dilakukan secara online. Dengan keadaan tersebut yang seharusnya keterampilan mahasiswa dalam menggunakan media elektronik dapat dikembangkan, menjadi terhambat.

Keberadaan sekolah terbuka yang masih dipandang sebelah mata ini, berakibat kurang diperhatikannya pula guru bina yang mengajar di sekolah tersebut. Guru tidak memiliki keterampilan dalam membuat media pembelajaran elektronik, yang sebenarnya penting untuk mengembangkan website sekolah terbuka. Sehingga, guru hanya bisa mengajar secara konvensional saja. Padahal dengan media pembelajaran yang menarik akan membuat sekolah terbuka ini lebih diminati.

Kemunculan sekolah terbuka yang tergolong masih baru ( 2 tahun), membuat calon siswa dan orang tua tidak mengetahui informasi dari keunggulan sekolah terbuka ini. Dengan bersekolah di sekolah terbuka, siswa dapat mendapatkan kemudahan melaksanakan pembelajaran, karena pembelajarannya tidak perlu dilaksanakan secara real time atau dapat dilakukan secara asinkronus atau tanpa tatap muka secara langsung. Dengan cara ini siswa dapat mendapatkan pendidikan dengan waktu yang fleksibel sekaligus pengalaman bekerja apabila sambil bekerja. Ijasah yang diperoleh siswa memakai nama sekolah induk yang memiliki kualitas yang bagus, tanpa mencantumkan nama sekolah terbuka. Sehingga, pengembangan sekolah terbuka melalui pelatihan pembuatan media pembelajaran berbasis elektronik dan perbaikan website, diharapkan dapat menarik calon siswa khususnya lulusan SMP, untuk melanjutkan sekolah ke jenjang SMA.

Penggunaan teknologi sudah sangat biasa digunakan di daerah perkotaan, kemudian bagaimana dengan penggunaan teknologi di daerah pedesaan? Sebenarnya penggunaan teknologi di daerah pedesaan juga sudah sangat umum, hanya saja pemanfaatannya yang masih belum maksimal. Oleh karena itu, perlu adanya upaya untuk terus mensosialisasikan pemanfaatan teknologi, terutama di bidang pendidikan, karena teknologi sangat dekat hubungannya dengan pentransferan ilmu pengetahuan. Sekolah Terbuka, SMAT Ar-Rahmah, secara geografis berada di lingkungan pedesaan yang pemanfaatan teknologi di bidang pendidikannya belum dilakukan secara maksimal. Pembelajaran yang seharusnya dilakukan dengan sinkronus (tatap muka) dan asinkronus (tanpa tatap muka), hanya dilakukan secara sinkronus saja secara konvensional. Hal ini dikarenakan belum adanya fasilitas dalam mendukung pelaksanaan pembelajaran asinkronus.

Program Pengabdian kepada Masyarakat ini dilakukan untuk mengembangkan pembelajaran asinkronus di SMAT ArRahmah. Pengembangan pembelajaran asinkronus dilakukan melalui media elektronik berupa website yang dikelola oleh sekolah. Website ini digunakan seaai temapat untuk mengupload bahan ajar yang 
dihasilkan guru setelah pelatihan. Secara singkat, permasalahan yang ada adalah keterampilan guru belum memadai dalam membuat media pembelajaran elektronik, dan website sekolah belum dikelola dengan maksimal. Berdasarkan permasalahan tersebut, solusi yang ditawarkan dalam mengembangan Sekolah Terbuka ArRahmah meliputi: 1) Pengembangan media pembelajaran elektronik oleh guru, cara yang digunakan dalam pengembangan website sekolah terbuka adalah dengan pelatihan pembuatan media elektronik kepada guru mata pelajaran; 2) Peningkatan keterampilan guru melalui pembuatan media pembelajaran elektronik. Melalui kegiatan ini, keterampilan guru sekaligus dapat ditingkatkan, yang mencakup keterampilan membuat media pembelajaran elektronik dan keterampilan menggunakan media pembelajaran online; dan 3) Pengembangan website SMAT Ar-Rahmah Jonggol, untuk memfasilitasi dalam menyelenggarakan sekolah terbuka. Website ini digunakan sebagai perantara atau tempat menyimpan media pembelajaran yang dapat diunduh oleh siswa dan dipelajari secara mandiri.

\section{MATERI DAN METODE}

Metode pelaksanaan yang digunakan dalam kegiatan pengabdian ini adalah ABCD (Assets Based Community Development). Assets Based Community Development merupakan suatu konsep pengembangan masyarakat yang didasarkan pada aset lokal yang terdapat di suatu wilayah. Wilayah tersebut memiliki aset yang kemudian dapat dikembangkan sehingga dapat digunakan untuk mengatasi permasalahan di wilayah tersebut. Menurut Green \& Haines (2015) dalam Asset Based and Community Development menjelaskan bahwa terdapat 7 modal yang bisa dikembangkan dalam ABCD: 1) modal fisik (physical capital) yang terdiri dari bangunan dan infrastruktur; 2) modal finansial (finansial capital) yang berupa dukungan keuangan; 3) modal lingkungan (environmental capital) berupa potensi alam; 4) modal teknologi (technological capital) yang berupa teknologi digital; 5) modal manusia (human capital) yang berupa sumber daya manusia; 6) modal sosial (social capital) yang berupa perilaku; dan 7) modal spiritual (spiritual capital) yang berupa pemberian bantuan emphaty, perhatian, dan kasih sayang. Pengembangan modal yang menjadi fokus dalam pengabdian ini adalah modal teknologi dan modal manusia. Sedangkan langkah-langkah pelaksanaan program pengabdian ini adalah: 1) observasi lapangan; 2) koordinasi dengan mitra; 3) sosialisasi program; 4) pelaksanaan program, dan 5) evaluasi.

Kegiatan pengabdian kepada masyarakat ini dilaksanakan di SMAT Ar-Rahmah Jonggol. SMAT Ar-Rahmah Jonggol merupakan salah satu dari SMA terbuka yang ada di Kecamatan Jonggol. SMAT Ar-Rahmah Jonggol beralamat di Jalan Kampung Karni, Desa Jonggol, Kecamatan Jonggol, Kabupaten Bogor, Jawa Barat. Sekolah Ar-Rahmah Jonggol ini berada di bawah Yayasan ArRahmah, dan memiliki sekolah pada tingkatan SD, SMP dan SMA. SMA Terbuka ini memiliki 25 guru bina yang digunakan sebagai subyek dalam kegiatan ini. Tugas guru disini adalah memberikan pembelajaran kepada siswa-siswa. Guru melakukan kegiatan pembelajaran yang diadakan secara tatap muka langsung atau. Padahal, idealnya, pelaksanaan sekolah terbuka dilakukan secara sinkronus (melalui tatap muka) dan asinkrinus (tanpa tatap muka).

Pelaksanaan kegiatan pengabdian ini difokuskan pada perbaikan e-learning di SMAT Ar-Rahmah yang meliputi perbaikan website, pengembangan media pembelajaran, dan peningkatan keterampilan guru. Cara yang digunakan dalam pengembangan sekolah terbuka tersebut adalah pelatihan pembuatan emedia kepada guru mata pelajaran, kemudian media yang dihasilkan digunakan untuk mengembangkan e-learningnya melalui website. Peserta adalah guru SMAT Ar-Rahmah yang berjumlah 25 orang. Alur gambaran IPTEK dapat dilihat pada Gambar 1. 
Gambar 1. Gambar IPTEK Pelatihan Pembuatan Media Pembelajaran Elektronik.

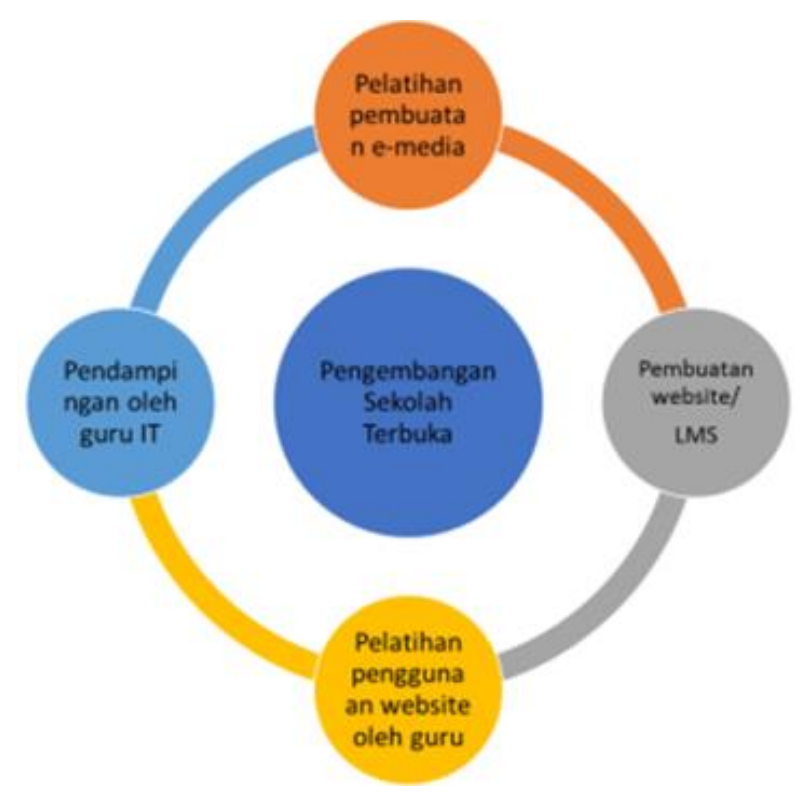

HASIL DAN PEMBAHASAN

Langkah-langkah kegiatan pengabdian kepada masyarakat ini adalah: 1) Observasi Lapangan, observasi lapangan bertujuan untuk mengamati situasi dan keadaan sekolah yang direncanakan sebagai obyek sasaran; 2) Koordinasi dengan mitra, dilakukan terhadap Guru dan Kepala Sekolah untuk menentukan kesepakatan mufakat dalam melaksanakan program pengembangan sekolah mitra yaitu Sekolah Terbuka SMAT Ar-Rahmah; 3) Sosialisasi Program, sosialisasi program bertujuan untuk memberikan informasi tentang rencana pelaksanaan program kepada guruguru dan kepala sekolah mitra, sehingga dapat melakukan persiapan sebelumnya; 4) Pelaksanaan Program, berupa demonstrasi tentang pelatihan pembuatan media pembelajaran elektronik, kompetisi guru dalam meningkatkan keterampilan dalam membuat media pembelajaran elektronik, monitoring pendampingan, dan pembuatan dan pengembangan website; 5) Evaluasi Kegiatan, mengevaluasi perkembangan pelaksanaan kegiatan yang dilaksanakan oleh guru serta memberikan saran dalam pengembangan sistem sesuai dengan kebutuhan.

\section{Observasi Lapangan}

Observasi lapangan dilakukan dengan dua kegiatan, yaitu observasi terhadap kondisi lingkungan sekolah dan observasi tentang kesiapan guru dalam melaksanakan pembelajaran jarak jauh. Berdasarkan hasil observasi kondisi lapangan diperoleh, Sekolah Terbuka SMAT Ar-Rahmah adalah salah satu dari dua SMA Terbuka yang ada di Kecamatan Jonggol Kabupaten Bogor, Jawa Barat. SMAT Ar-Rahmah tercatat memiliki 25 tenaga pendidik. Gedung belajar SMAT Ar-Rahmah terletak di lokasi yang berbeda dengan sekolah induk.

Selanjutnya, observasi kesiapan guru dalam melaksanakan pembelajaran jarak jauh dilakukan dengan pengisian kuesioner oleh guru. Observasi dilakukan berdasarkan 6 indikator berupa pertanyaan yang telah disusun yang berkaitan dengan pengimplementasian teknologi informasi kepada siswa di SMAT Ar-Rahmah Jonggol. Hasil observasi tersebut diuraikan pada Tabel 1.

Tabel 1. Hasil Observasi Penggunaan Media Pembelajaran Elektronik.

\begin{tabular}{clllll}
\hline No & \multicolumn{3}{c}{ Pertanyaan } & Hasil \\
\hline 1 & Apakah sarana dan prasarana di & SMAT Ar-Rahmah telah memiliki \\
& sekolah Anda sudah mendukung & laboratorium komputer dan beberapa \\
& terjadinya pembelajaran berbasis IT? & unit komputer. Guru berpendapat bahwa \\
& & sarana dan prasarana penunjang \\
& & pembelajaran berbasis IT masih \\
& & memerlukan koneksi internet untuk \\
& & mempercepat mengakses media \\
\end{tabular}


2 Apakah Anda telah menggunakan Pembelajaran berbasis IT dilakukan pembelajaran berbasis IT, dan dengan melalui tatap muka dengan cara apa?

menggunakan media pembelajaran elektronik atau perangkat lunak berupa PPT, dan perangkat keras berupa LCD. Pembelajaran secara online dilakukan oleh satu guru.

3 Apakah Anda setuju dengan penerapan pembelajaran berbasis IT di sekolah terbuka?

Seluruh guru menyatakan setuju apabila pembelajaran dilakukan dengan memanfaatkan IT, dengan alasan bahwa pembelajaran akan lebih efisien, media belajar lebih bervariasi, kualitas pembelajaran semakin meningkat

4 Menurut Anda apa kelebihan Ada beberapa kelebihan menggunakan menggunakan pembelajaran berbasis media pembelajaran berbasis IT IT (jika diterapkan di sekolah Anda)? menurut persepsi guru SMAT ArRahmah, diantaranya adalah: 1) siswa lebih bersemangat dalam mengikuti pelajaran; 2) pembelajaran lebih menyenangkan; 3) lebih mudah mencari sumber belajar; dan 4) pembelajaran lebih menarik.

5 Menurut Anda apa kekurangan menggunakan pembelajaran berbasis IT (jika diterapkan di sekolah Anda)? Ada beberapa kekurangan menggunakan media pembelajaran berbasis IT menurut persepsi guru SMAT ArRahmah, diantaranya adalah: 1) masih banyak guru dan siswa yang belum menguasai IT; 2) kurangnya sarana dan prasarana pendukung, terutama jaringan internet; dan 3) kekhawatiran guru apabila siswa membuka website yang tidak diperbolehkan.

6 Solusi apa saja yang bisa Anda berikan Solusi yang ditawarkan oleh guru antara untuk mengatasi kekurangan pembelajaran berbasis IT di sekolah terbuka? lain: 1) mulai sedikit demi sedikit memperkenalkan pembelajaran IT kepada siswa; 2) memberikan pelatihan pembuatan media pembelajaran berbasis IT bagi guru-guru; dan 3) memberikan pelatihan penggunaan pembelajaran berbasis IT bagi siswa. 


\section{Koordinasi dengan Mitra}

Kegiatan koordinasi dilaksanakan di tempat mitra yaitu Sekolah Terbuka SMAT ArRahmah Jonggol yang menginduk ke SMAN 1 Jonggol. Sekolah mitra memiliki beberapa kontribusi, diantaranya adalah: Pertama, sekolah mitra memfasilitasi kegiatan dengan menyediakan ruangan pelatihan dan kemudahan dalam perijinan. Kedua, sekolah mitra memberikan pengarahan kepada guruguru yang akan mengikuti pelatihan pembuatan media pembelajaran elektronik. Pelatihan dilakukan sebanyak 3 kali pertemuan, sedangkan kegiatan pendampingan dilakukan selama 2 minggu. Ketiga, sekolah mitra menunjuk salah satu guru yang ahli di bidang IT untuk bersamasama merancang website yang akan digunakan untuk pembelajaran asinkronus. Pemilihan guru ahli IT dimaksudkan agar website/LMS dapat terus dirawat untuk keberlanjutan program.

\section{Sosialisasi Program}

Sosialisasi program bertujuan untuk memberikan informasi tentang rencana pelaksanaan program kepada guru-guru dan kepala sekolah mitra, sehingga dapat melakukan persiapan sebelumnya. Sosialisasi yang dilakukan mencakup peralatan yang harus dipersiapkan oleh peserta pelatihan, alat dan bahan yang dipersiapkan oleh pihak sekolah, dan menetapkan hari pelatihan.

\section{Pelaksanaan Program}

Pelaksanaan Program, berupa demonstrasi tentang pelatihan pembuatan media pembelajaran elektronik, kompetisi guru dalam meningkatkan keterampilan dalam membuat media pembelajaran elektronik, monitoring pendampingan, dan pembuatan dan pengembangan website. Kegiatan pelatihan dilakukan dengan kegiatan pembuatan media pembelajaran elekronik dengan menggunakan program Sparkol Video Scribe, Power Point, dan Camtasia Studio yang dilakukan sebanyak 3 kali pertemuan dan 2 minggu kegiatan pendampingan. Setiap peserta pelatihan diwajibkan menghasilkan 2 media yang berbeda.

Gambar 2. Kegiatan Pelatian yang Di lakukan oleh tim tutor.

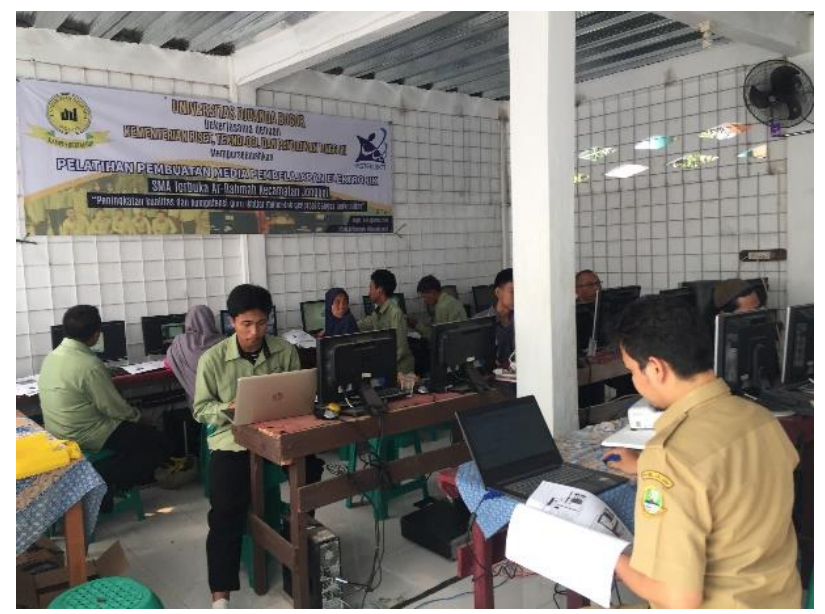

Kegiatan pendampingan dilakukan selama 2 minggu. Kegiatan pendampingan dilakukan untuk memberikan bantuan berupa pelatihan tambahan bagi peserta yang mengalami kesulitan secara teknis. Selain itu, kegiatan ini digunakan sebagai tahap finalisasi produk sebelum diupload di website.

Gambar 3. Kegiatan Pendampingan oleh tim tutor.

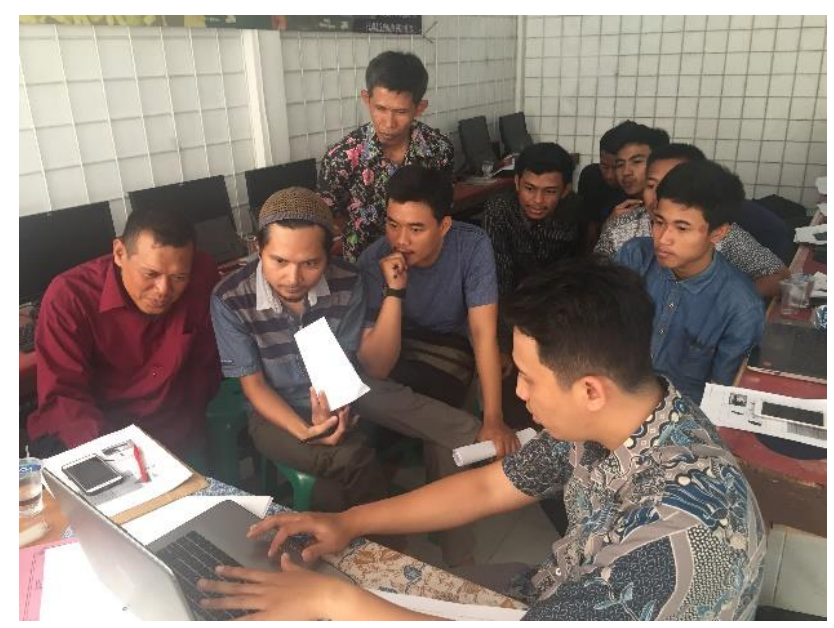

\section{Evaluasi Kegiatan}

Evaluasi kegiatan dilakukan untuk memberikan saran dalam pengembangan sistem sesuai dengan kebutuhan. Berdasarkan keseluruhan tahapan yang telah dilakukan, didapatkan hasil bahwa setelah

mengikuti pelatihan dan pendampingan, mayoritas peserta yang berjumlah 25 orang 
telah mampu mengimplementasikan materi pelatihan. Sebanyak $80 \%$ atau 20 peserta telah mampu menghasilkan media pembelajaran minimal dua buah media. Pelatihan ini menghasilkan 40 media pembelajaran yang diupload ke website pembelajaran sekolah yang telah dibuat oleh tim pelatih.

Untuk keberlanjutan program pelatihan ini, website dan pembuatan domain difasilitasi selama 1 tahun, dan dipantau oleh guru IT. Demikian pula dengan media pembelajaran yang dibuat oleh peserta. Peserta berhak mendapatkan bantuan dari guru IT apabila merasa kesulitan dalam mengoperasikan media pembelajaran online. Untuk skema keberlanjutan program ada pada Gambar 4. Gambar 4. Skema Keberlanjutan Program.

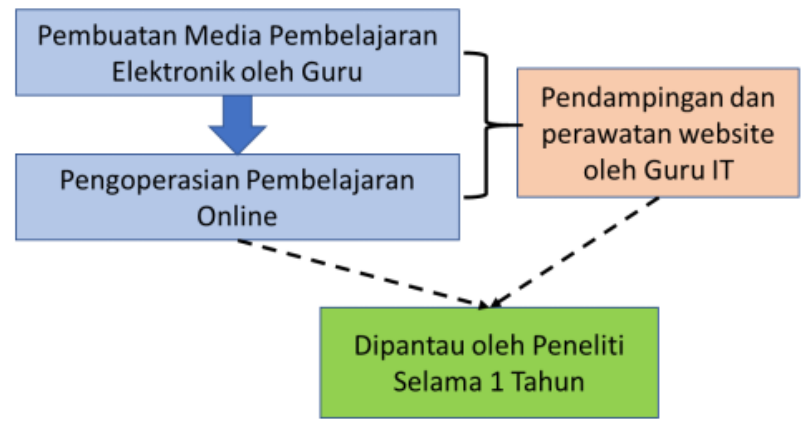

\section{KESIMPULAN}

Kegiatan Pengabdian bagi Masyarakat yang dilakukan ini berupa kegiatan pelatihan yang bertujuan untuk mengadakan pelatihan dan pendampingan dalam pembuatan media pembelajaran interaktif bagi guru-guru SMA Terbuka di Kecamatan Jonggol Kabupaten Bogor. Kegiatan ini memiliki target supaya guru sekolah terbuka dapat memiliki dan meningkatkan kemampuannya dalam membuat media pembelajaran dengan aplikasi yang dipelajari. Aplikasi yang digunakan dalam membuat media pembelajaran elektronik ini adalah Sparkol Video Scribe, Power Point, dan Camtasia Studio. Metode dari kegiatan ini menggunakan metode ABCD (Assets Based Community Development) yang difokuskan pada pengembangan aset manusia (human capital). Metode ini memiliki prinsip memaksimalkan potensi di sebuah wilayah kerja sehingga dapat mengatasi permasalahan di wilayah tersebut. Dalam hal ini, guru-guru di SMA Terbuka Ar-Rahmah ditingkatkan keterampilannya sehingga dapat menghasilkan media yang inovatif dan dapat mengatasi permasalahan pembelajaran di sekolahnya.

\section{Implikasi}

Pelatihan ini dapat meningkatkan keterampilan guru sekolah terbuka dalam pembuatan media pembelajaran yang lebih inovatif. Dengan adanya media pembelajaran yang dihasilkan oleh guru-guru sekolah terbuka, khususnya guru-guru di SMA ArRahmah, maka siswa dapat melakukan pembelajaran jarak jauh yang seharusnya menjadi ciri khas dari sekolah terbuka. Waktu yang digunakan siswa untuk belajar lebih fleksibel, namun tetap mendapatkan materi yang mumpuni.

\section{UCAPAN TERIMAKASIH}

Segala puji dan syukur senantiasa penulis panjatkan kepada Allah Azza Wajallah, atas segala nikmat, rahmat dan karunia-Nya sehingga jurnal pengabdian penelitian yang berjudul Pemanfaatan Abu Sekam Padi Sebagai Bahan Pembuatan Dalam Paving Block dapat terselesaikan meskipun dalam susunan yang sangat sederhana. Penulis menyadari sepenuhnya bahwa selama penyusunan jurnal pengabdian program penelitian sekam padi ini terdapat banyak kesulitan, tantangan dan hambatan. Namun penulis yakin bahwa Allah Ta'alllah akan memudahkan urusan setiap hamba-Nya yang bekerja keras dan tidak putus asa.

Ucapan terima kasih dan penghargaan yang setinggi-tingginya penulis persembahkan kepada BAPPEDA (Badan Perencanaan dan Pembangunan Daerah) yang telah membantu dalam melaksanakan pengabdian ini.

Melalui kesempatan ini penulis ucapkan terima kasih yang sedalam dalamnya dan setulus - tulusnya kepada seluruh pihak untuk setiap nasihat dan iringan do'a yang selalu di panjatkan untuk kebaikan penulis di 
dunia dan akhirat serta yang telah berkontribusi dalam kegiatan pengabdian dengan penuh keikhlasan dan kesungguhan dalam memberikan bimbingan, petunjuk serta arahan selama melaksanakan program pengabdian ini, diantaranya kepada : bapak Idim Dimyati selaku kepala Desa Sirnajaya dan jajaran staf Desa Sirnajaya; ketua kedusunan desa Sirnajaya; ketua Rw, ketua Rt, dan seluruh masyarat Desa Sirnajaya; ibu - ibu PKK Desa Sirnajaya; Ibu Een selaku pemilik penggilingan padi; karangtaruna desa Sirnajaya; pemuda dan pemudi Desa Sirnajaya.

\section{UCAPAN TERIMAKASIH}

Pelatihan pembuatan media pembelajaran elektronik ini merupakan bagian dari program pengabdian kepada masyarakat melalui PKM yang diselenggarakan oleh Kemenristekdikti. Oleh karena itu kami mengucapkan terima kasih kepada Kemenristekdikti yang telah membiayai kegiatan pelatihan. Kami juga mengucapkan terima kasih kepada seluruh pihak yang telah mendukung terselenggaranya kegiatan ini, tak terkecuali Universitas Djuanda Bogor dan SMA Ar-Rahmah yang telah memberikan fasilitas baik materiil maupun non-materiil.

\section{DAFTAR PUSTAKA}

Anwariningsih, H. S. (2014). Kesiapan penggunaan ICT pada sekolah dasar di daerah rural dalam perubahan paradigma pembelajaran. Seminar Nasional dan Call for Papers UNIBA. Banjarmasin: UNIBA.

Dinas Pendidikan Provinsi Jawa Barat. (2017). Petunjuk pelaksanaan pembelajaran sekolah menengah atas terbuka. Bandung: Dinas Pendidikan Provinsi Jawa Barat.

Green, G. P., \& Haines, A. (2015). Asset Building \& Community Development. SAGE Publication.

Latip, A. (2017, Desember 31). Kompasiana. Retrieved from Tantangan SMA Terbuka di Jawa Barat: https://www.kompasiana.com/altip/5a4 85a66dd0fa835ed469da2/tantangansma-terbukadi-jawa-barat

Mayer. (2009). Multi media learning, prinsipprinsip dan aplikasi. Yogyakarta: Pustaka Pelajar.

Muhson, A. (2010). Pengembangan media pembelajaran berbasis teknologi informasi. Jurnal Pendidikan Akuntansi Indonesia, 8(2), 1-10.

Republik Indonesia. (2003). Undang-undang pasal 3 nomor 20. Jakarta: Kemendikbud.

Republik Indonesia. (2013). Permendikbud nomor 72. Jakarta: Kemendikbud. 